\title{
To Quest Common Dangerous Bacterial Attack in Drinking Water
}

\section{Sisir Nandi*, Sarfaraz Ahmed and Deepak Teotia}

Division of Pharmaceutical Chemistry, Global Institute of Pharmaceutical Education and Research, Kashipur, India

\begin{abstract}
Buried ground water is very indispensable because it is major sources for the uses of humans, animals, industry and domestic purposes. The presence of pathogenic bacteria in drinking water is one of the great issues now-adays. The present article summarizes the dangerous effects, common methods of detection, recent outbreaks and possible plan to control the contamination of various common bacteria in drinking water to alert general public to be safe and healthy.
\end{abstract}

Keywords: Ground water; Drinking water; Gram-negative bacteria; E. coli; Salmonella; Vibrio; Shigella; Klebsiella; Pseudomonas; Staphylococci; Enterobacteria

\section{Introduction}

\section{No water means no life}

Water is life. Lives do not exist without water for a single moment. It is proved that three-fourths of the Earth's surface is covered with water, and one-fourth is land. Out of these, only $3 \%$ is fresh water and $97 \%$ is found in seas and oceans. Of this $3 \%, 1.7 \%$ is buried underground, $1.7 \%$ is in glaciers and the ice caps of Antarctica and Greenland, a small fraction in other large water bodies, $0.001 \%$ in the air as vapor, clouds (formed of ice and liquid water suspended in air) and precipitation [1].

\section{Bacterial attack in drinking water}

Therefore, major source of drinking water is hidden as ground water. Buried ground water can be contaminated by means of different sources of pathogenic bacteria including human and animal wastes, septic tanks discharge, drainage sewages, floods, insects, rodents or animals and natural soil/plant bacteria penetrated through well. Drinking water can be infected by total coliforms and other subgroups including E. coli, Salmonella, Vibrio, Shigella, Klebsiella, Pseudomonas, Staphylococci and Enterobacteria which get into lakes, pools and water supplies. People become infected when a contaminated city or town water supply has not been properly treated with chlorine or when people accidentally swallow contaminated water while swimming in a lake, pool, or irrigation canal. Dangerous microbial growth causes potential health hazards including intestinal infections, dysentery, hepatitis, typhoid fever, cholera, and other illnesses. Acute water borne infections are major health issues in developing as well as developed countries. According to the World Health Organization, the mortality of water associated diseases exceeds 5 million people per year. From these, more than $50 \%$ are microbial intestinal infections, with cholera standing out in the first place. Children below five years of old, primarily in Asian and African countries, are majorly affected by microbial diseases transmitted through drinking water [2].

Environmental soil, vegetation and faeces of all warm-blooded animals and humans contain total coliforms. Faecal coliform bacteria are a subgroup of total coliform bacteria and are unlikely cause illness. $E$. coli is a subgroup of the faecal coliform group which may enter into the water supplies. More than hundred strains of Escherichia coli are present in the intestine as symbiotic organisms. One of the harmful strains is $E$. coli O157:H7 (Figure 1) which was first recognized as a cause of illness during an outbreak in 1982. On December 12, 2017, Centers for Disease Control and Prevention and Food and Drug Administration reported

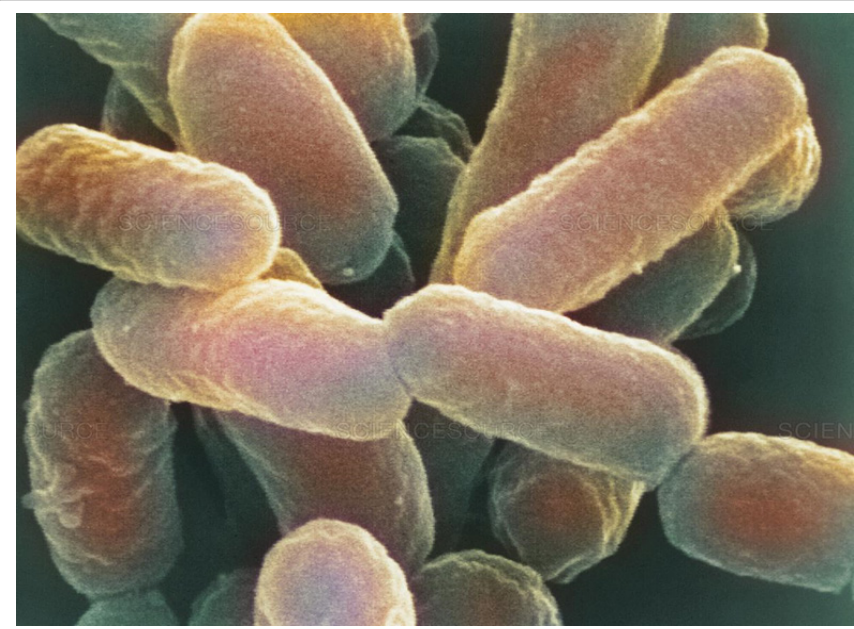

Figure 1: Colored scanning electron micrograph (SEM) of Escherichia coli 0157:H7 bacteria [5].

a multistate outbreak of 24 Shiga-toxin producing E. coli O157:H7 infections in 15 states. E. coli O157:H7 is an emerging cause of food borne and water borne illnesses. Human or animal faeces contaminated with E. coli $\mathrm{O} 157: \mathrm{H} 7$ can be transmitted to other human or animal through contact of dirty hands, infected objects and drinking water. Conventional method for the detection of non-sorbitol fermenting $\mathrm{E}$. coli O157:H7 can be carried out by the use of sorbitol MacConkey agar (SMAC), which consists of bile salts, a carbohydrate source, sorbitol and an indicator [3]. E. coli produces verotoxin in intestinal lumen and causes acute bloody diarrhea, dehydration and gastroenteritis, stomach cramps, nausea and vomiting, urinary tract infection (UTI). E. coli can attack the blood or kidneys and produces pale skin, fever, weakness, bruising and passing only small amounts of urine [4,5].

In October 2010, Cholera pandemic was reported from Haiti.

${ }^{*}$ Corresponding author: Sisir Nandi, Division of Pharmaceutical Chemistry, Globa Institute of Pharmaceutical Education and Research, Kashipur, India, Tel: +91 7500458478; E-mail: sisir.iicb@gmail.com

Received February 21, 2018; Accepted March 16, 2018; Published March 23, 2018

Citation: Nandi S, Ahmed S, Teotia D (2018) To Quest Common Dangerous Bacterial Attack in Drinking Water. J Bioanal Biomed 10: 40-42. doi:10.4172/1948-593X.1000202

Copyright: $\odot 2018$ Nandi S, et al. This is an open-access article distributed under the terms of the Creative Commons Attribution License, which permits unrestricted use, distribution, and reproduction in any medium, provided the original author and source are credited. 
Citation: Nandi S, Ahmed S, Teotia D (2018) To Quest Common Dangerous Bacterial Attack in Drinking Water. J Bioanal Biomed 10: 40-42. doi:10.4172/1948-593X.1000202

A number of 16,111 patients were hospitalized due to acute watery diarrhea and 992 cholera deaths, 620 of which occurred among hospitalized patients. While there were 815,000 cases of cholera in Haiti between 2010 and 2017, Yemen has exceeded that number in just six months. On 30 September 2017, the World Health Organization reported 771,945 cases of cholera with 2,132 death cases [6]. Vibrio is a group of aquatic bacteria, of which Vibrio cholerae O1 and $\mathrm{O} 139$ strains produce exotoxin and cause epidemic cholera [7]. Vibrio cholerae is a virulent gram-negative bacterium with a curved rod and a single flagellum (Figure 2). The exotoxin can bind the intestinal cell membrane receptor and stimulate the efflux of water and essential ions such as sodium, potassium, chloride and carbonate from the cells which predominantly causes diarrhea, hyponatremia, hypovolemia, muscular weakness and circulatory arrest [8]. Rapid Detection of $V$. cholerae O1 can be done by using the Cholera SMART kit which consists of a reaction vial bearing a lyophilized colloidal-gold-labeled monoclonal antibody, COLTA and a SMART device [9].

Shigella species are $S$. dysenteriae serotype 1, S. sonnei and S. flexneri which are Gram-negative, facultative anaerobic, non-spore forming, non-motile, straight rod-shaped family of Enterobacteriaceae. S. dysenteriae serotype 1 (Figure 3) produces higher levels of a cytotoxic Shiga toxin in compare with the other two strains. Shigella is the causative organisms of dysentery and gastroenteritis, outbreak occur in Ioannina, Greece in the year of 2000. Recent outbreaks of dysentery caused by $S$. flexneri and S. sonnei were reported from various parts of the West Bengal (2007), Kerela (2009) and Maharashtra (2010) [10]. Just like the cholera bacterium, it attacks the large intestinal lumen, engulfs epithelial cells resulting perforation, bleeding, abdominal cramps, anal pain, and bloody stool [11] and causes death of a number of 74,000 to 600,000 per year [12]

Klebsiella is omnipresent in environment and surface water. It is a non-disease forming commensal microflora of the gastro intestinal tract but may be involved in urinary tract infection, particularly in females, penetrating through the urethra and lesion in bowel. Klebsiella pneumonia (Figure 4) is one of the Klebsiella species isolated from water. Virulence factors such as pili, serum resistance and siderophore was isolated and compared them with clinical isolates. $K$. pneumoniae causes infection on exposure to the respiratory tract bloodstream $[5,13]$.

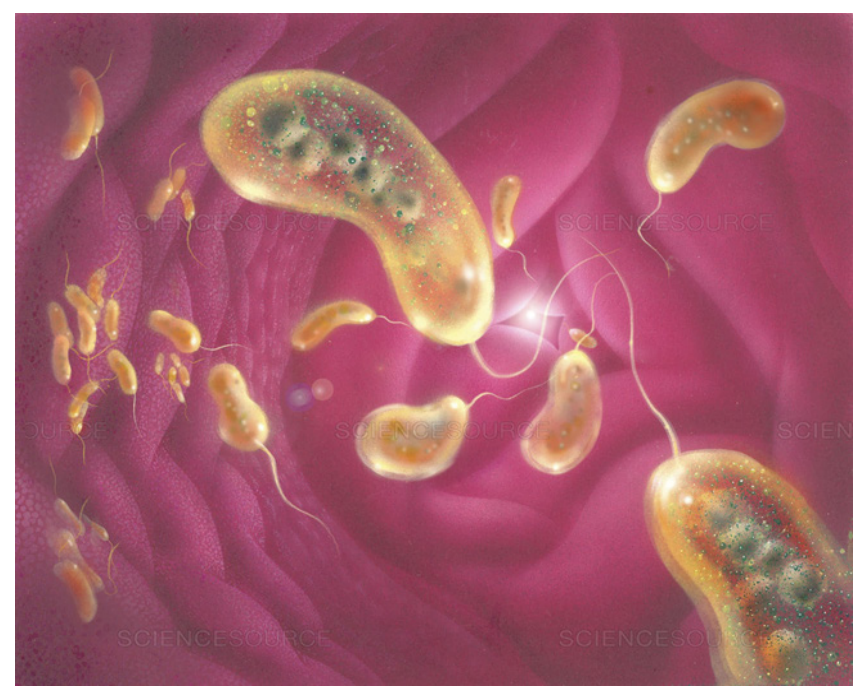

Figure 2: Colored scanning electron micrograph of Vibrio cholera [5].

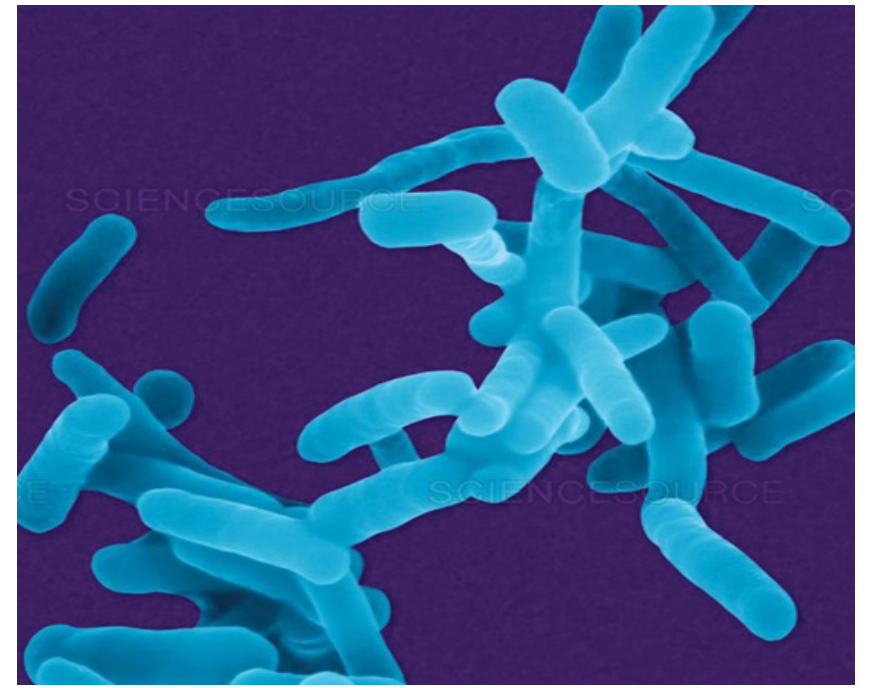

Figure 3: SEM of S. dysenteriae serotype 1 [5].

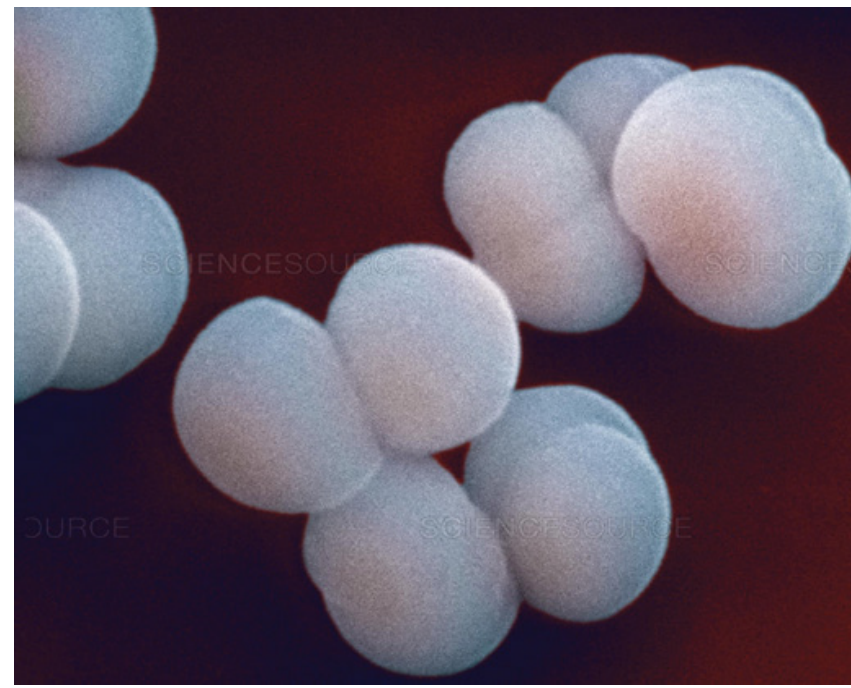

Figure 4: SEM of $K$. pneumoniae [5].

Pseudomonas species are very frequent in portable packaging water, soil, plumbing taps and pipes. It is a polarly flagellated, aerobic, rod-shaped Gram-negative bacterium (Figure 5). Pseudomonas aeruginosa is very dangerous if enter into the body through wounds, infected surgical instruments and eyes also. It can colonize to produce septicemia, meningitis, cystic fibrosis and pulmonary infections $[5,14]$.

Out of many Staphylococci species, S. aureus, S. epidermidis and S. saprophyticus cause disease in humans. Staphylococcus aureus is mostly dangerous. Outbreak of the same was recently reported on 28 October 2014 by the South Western Sydney Local Health District [15]. It is an aerobic or anaerobic Gram-positive, non-motile, nonspore-forming, catalase- and coagulase-positive, grape-like assembly (Figure 6) colonized in well water coming from sewage. S. aureus enterotoxin was found in rural drinking water and grown in packaged foods which produce enterotoxin within a few hours. The consumption of these infected foods causes gastroenteritis characterized by projectile vomiting, diarrhoea, fever, abdominal cramps, electrolyte imbalance and loss of fluids [16]. Multiplication in tissues can result 
Citation: Nandi S, Ahmed S, Teotia D (2018) To Quest Common Dangerous Bacterial Attack in Drinking Water. J Bioanal Biomed 10: 40-42. doi:10.4172/1948-593X.1000202

in manifestations such as boils, skin sepsis, post-operative wound infections, enteric infections, septicaemia, endocarditis, osteomyelitis and pneumonia. The onset of clinical symptoms for these infections is relatively long, usually several days [17]. Wang and co-workers developed loop-mediated isothermal amplification (LAMP) method for the rapid identification of Staphylococcus aureus $[5,18]$.

One of the vulnerable family members of Enterobacteriaceae is extended-spectrum $\beta$-lactamase (ESBL)-producing Enterobacter. In November 2009 and June 2010, a total of 101 sachet-packaged water bags were bought from street vendors in 9 of 24 municipalities (covering residential areas and slums) of the city of Kinshasa [19].

\section{Conclusion and Expert's Opinion}

Ground water is going to pollute due to dangerous bacterial attack. So, safe drinking water for all is one of the major challenges now-adays. Microbiological control of drinking water should be the norm everywhere. People affected by bacterial diarrheal diseases are those

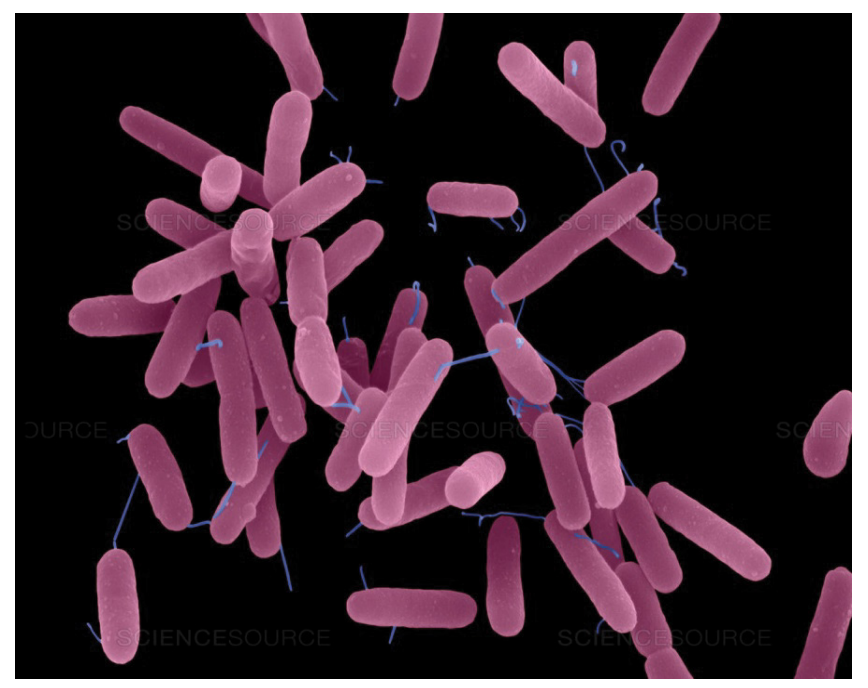

Figure 5: SEM of Pseudomonas aeruginosa [5].

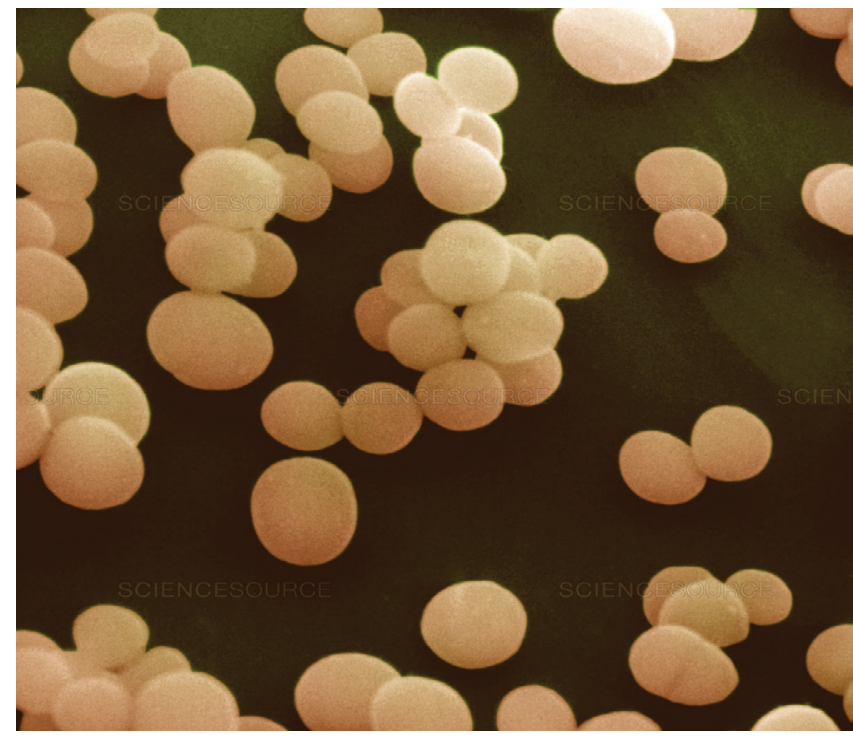

Figure 6: Scanning electron micrograph of $S$. aureus [5]. with the lowest financial resources and poorest hygienic facilities. Gram negative bacteria can become dangerous by producing biofilm via quorum sensing mechanisms and cause antibiotic resistant. Therefore, public must aware to be safe in drinking water and free from the dangerous bacterial attack. On application of pressure standing, solar disinfection, reverse osmosis, filtration, chemical oxidation through chlorination of the ground water can produce portable for the drinking to minimize bacterial infections. Water should be boiled and cooled at a normal temperature and filtered through cloth or clay vessels. Further, Chlorine, $\mathrm{KMnO}_{4}$ and alum can be added as antiseptic to prevent bacterial infection in reserved water.

\section{Acknowledgement}

Authors acknowledge "Water for Welfare: An Uttarakhand Initiative" (WFWUI) a Virtual Centre of Excellence, having its secretariat at IIT Roorkee (vide O.M. No.293//I/2004-034(3)/65/03 dated August 5, 2004 and No.1129/I/2005-04(3)/65/03 dated March 05, 2005) for the grant.

\section{References}

1. Gleick PH (1993) Water in Crisis: A Guide to the World's Freshwater Resources Oxford University Press.

2. WHO (2008) Guidelines for Drinking-water Quality, Incorporating 1st and 2nd Addenda. $3^{\text {rd }}$ edn. WHO, Geneva, Switzerland.

3. March SB, Ratnam S (1986) Sorbitol-MacConkey medium for detection of Escherichia coli O157:H7 associated with hemorrhagic colitis. J Clin Microbiol 23: 869-872.

4. https://www.freedrinkingwater.com/water-contamination/ecoli-bacteriaremoval-water.htm

5. https://www.sciencesource.com/archive/

6. https://en.wikipedia.org/wiki/2016\%E2\%80\%9318_Yemen_cholera_outbreak

7. Glass RI, Libel M, Brandling-Bennet AD (1992) Epidemic Cholera in the Americas. Science 256: 1524-1525.

8. Ali M, Emch M, Yunus M, Sack RB (2001) Are the environmental niches of Vibrio cholerae 0139 different from those of Vibrio cholerae $01 \mathrm{El}$ Tor? Int Infect Dis 5: 214-219.

9. Hasan JAK, Huq A, Tamplin ML, Siebeling RJ, Colwell RR (1994) A novel kit for rapid detection of Vibrio cholerae O1. J Clin Microbiol 32: 249-252.

10. Nandy S, Dutta S, Ghosh S, Ganai A, Rajahamsan J, et al. (2011) Foodborneassociated Shigella sonnei, India, 2009 and 2010. Emerg Infect Dis 17: 2072 2074.

11. Cabral JPS (2010) Water microbiology: Bacterial pathogens and water. Int $\mathrm{J}$ Environ Res Public Health 7: 3657-3703.

12. Mani S, Wierzba T, Walker RI (2016) Status of vaccine research and development for Shigella. Vaccine 34: 2887-2894.

13. Padschun R, Pietsch S, Höller C, Ullmann U (2001) Incidence of Klebsiella species in surface waters and their expression of virulence factors. App Environ Microbiol 67: 3325-3327.

14. Bartram J (2003) Heterotrophic plate counts and drinking-water safety: The significance of HPCs for water quality and human health. WHO Emerging Issues in Water and Infectious Disease Series. IWA Publishing, London.

15. Fletcher S, Boonwaat L, Moore T, Chavada R, Conaty S (2015) Investigating an outbreak of staphylococcal food poisoning among travellers across two Australian states. Western Pac Surveill Response J 6: 17-21.

16. Antai SP (1987) Incidence of Staphylococcus aureus, coliforms and antibioticresistant strains of Escherichia coli in rural water supplies in Port Harcourt. $J$ Appl Bacteriol 62: 371-375

17. LeChevallier MW, Seidler RJ (1980) Staphylococcus aureus in rural drinkingwater. Appl Environ Microbiol 39: 739-742.

18. Wang XR, Wu LF, Wang Y, Ma YY, Chen FH, et al. (2015) Rapid detection of Staphylococcus aureus by loop-mediated isothermal amplification. Appl Biochem Biotechnol 175: 882-891.

19. De Boeck H, Miwanda B, Lunguya-Metila O, Muyembe-Tamfum JJ, Stobberingh $\mathrm{E}$, et al. (2012) ESBL-positive enterobacteria isolates in drinking water. Emerg Infect Dis 18: 1019-1020. 